\title{
Identifying Factors for the Enrollment of Students towards Distance Education for Master's Course: A Student's Perspective
}

\author{
${ }^{1}$ Charlotte Mascreen, ${ }^{1}$ Yogesh Pai P., ${ }^{2}$ Rashmi Y. Pai \\ ${ }^{1}$ Manipal University, ${ }^{2}$ Poornaprajna Institute of Management
}

\begin{abstract}
Learning is the beginning of a need for perfection. In the knowledge era there is a need for change in learning and their mechanisms. There has been an increase on the thrust for higher education across the nations for better employment and quality of life. With an increase in the number of distance education institutes and increasing demand for the distance education in India, we explore in this paper the factors that are considered important for enrolling into master's course under distance education from the student's perspective. The study has identified nine factors that are affecting the enrollment of students towards distance education programme-associated, reputation, personal development, practical issues, personal concerns, competition and personal objectives, personal motivators, institutional status and personal satisfaction. These factors need to be examined by the educational institutes to better understand the requirements of the student community.
\end{abstract}

\section{Introduction}

There has been a phenomenal change in terms of the thrust towards learning across the world; both among the developed and developing countries that are faced with the challenge of education. Education at all levels contributes to economic growth through imparting general attitudes and discipline and specific skills necessary for a variety of workplaces [1]. In the global economy of the twenty-first century, organizations and companies are under increasing pressure to enhance lifelong learning among their employees, contributing to their professional development and productivity. In the present context keeping the employees away from their jobs is no longer an option as there is shortage of qualified and competent manpower and thus universities should reach out to them by launching distance education (DE) programs. Further with the change in the global scenarios of employment and recession the employees don't want to leave their jobs and ruin chances of promotion and stable incomes.

Providing higher education using traditional faceto-face teaching has for nearly a decade gradually given way to distance learning methods [2]. Distance education has also made it possible for a notable number of countries such as India, China, and Thailand to overcome geographic and socioeconomic challenges and to reach out to diverse segments of their population in need of educational services [3, 4]. With an annual Government spending of $\$ 30$ billion and private spending of $\$ 43.2$ billion, education is one of the largest capitalized sectors in India [5]. Moreover it is estimated that one in every five students has taken an online course, and the anticipated annual growth rate for online enrollments is well over 10 percent for the next decade [6]. Though, open and distance learning in India dates back to the 1960s; the enrollment in higher education was meager about 3\% during 1995 and are presently increasing steadily.

The largest level of participation in distance learning programs is exhibited by business schools than other professional fields [7]. The numbers of students enrolling for master's courses are comparatively less than the graduate courses and distance education provides an opportunity for pursuing higher education. Accordingly, our paper investigates the factors affecting the enrollment of students towards distance education with reference to master's course which is one of the key routes for career advancements. Though similar studies have been conducted in the developed countries, an attempt has been made to explore and identify the factors affecting the enrollment of students towards distance education in Indian context. The present paper is useful for educational universities to understand the requirements of their target segment; as distance learning programs are proving to be a popular way for colleges and universities to expand enrollments and grow into new markets to offset shrinking enrollments and declining resources in traditional campus-based courses and programs [8].

\section{Distance Education}

The terms "distance education", "online learning" and "distance learning" are often interchangeably used to describe the process of providing formal instruction to students in such a way that the instructor and the student can be separated by geography, time or both [9]. Distance education is defined today as a planned instruction that occurs far from the designated learning place, while applying advanced technologies [10]. Distance Education is also defined as learning through a variety of technological means, enabling students far away 
from the teaching place to acquire knowledge as if they were present at the lessons [11] or Distance education is 'a process to create and provide access to learning when the source of information and the learners are separated by time and distance, or both' [12] thus the distance learning courses provide alternative methods to acquire knowledge outside traditional classroom settings. The term 'distance education' was acknowledged in 1982 when the International Council for Correspondence Education changed its name to the International Council for Distance Education [13]. Most of what is now called 'distance education' is offered using some form of technology, either to deliver instructional materials and/or to teach courses. Interestingly, among the different types of globalization there is also learning globalization [14]; and twenty-first century universities can be successful, efficient and effective deliverers of education if they globalize their activities using satellite and/or electronic international multimedia communication [15].

\subsection{Theories of distance education}

The characteristic of distance education was summarized by [16] from their own review of the literature as: education imparted where the learner is physically separated from the teacher [17]; as a planned and guided learning experience [18, 19]; and consists of a two-way structure distinct from traditional classroom instruction [20]. Distance education has been looked at the higher level of independence or "learner control" [21] which is one of its feature. Developing a model to examine the concepts in terms of independence, competence and support; [22] notes that "control" is more than "independence". It was also affected by competence (ability and skill), and support (both human and material). "Transactional Distance", yet an another concept was established by [23]; wherein the "distance" is determined by the amount of communication or interaction which occurs between learner and instructor, and the amount of structure which exists in the design of the course. Greater transactional distance occurs when a course has more structure and less communication (or interaction). A continuum of transactions might exist in this model, from less distant, where there is greater interaction and less structure, to more distant where there may be less interaction and more structure.

\subsection{Previous Studies}

A variety of factors motivate adult students to take distance learning courses that could be drawn from literature. The main factor driving students to take distance learning courses are career development [24]; constraints of time, distance and finances [25]; access and time flexibility, opportunity to collaborate with students who live far apart, opportunity to collaborate with students of diverse backgrounds [26]; socializing and convenience factors [27]. Other motivators identified by research studies in the US include the instructor and supplemental material available [28]. All of the studies have been conducted in other countries and serve as valuable references, we should be cautious about trying to apply these results to other student populations, especially in India and thus the aim of our study is to find out the motivators or factors in selecting a distance education, which is based on a study conducted at Manipal, India.

\section{Study Methodology}

The scope of the present study is confined to the students who have enrolled for the master's programme (such as MBA, M.Com, M.Phil) and are in different phases of their enrollment under distance education from eight different universities. The present work is an exploratory study to determine the factors affecting the enrollment of students towards distance education. The primary data was collected for during the month of October 2011 which constituted of a field based visiting the home/office of the respondents. The data was collected using a structured questionnaire from the respondents adopting non-probability method of snowball sampling. About 55 questionnaires were distributed among which 48 were returned and considered for the study. The following factors were chosen to test how much they would influence a student's decision to take a distance learning course. They were identified from the literature reviewed as motivators for taking distance learning courses. For each of the factors, the respondents chose between five degrees of importance ranging from 'not important' to 'very important'. The list contained 25 factors or independent variables:

- Provides time flexibility

- Not required to be physically present in class

- Reputation of the course

- Reputation of the teacher

- Interest in subject matter

- Reputation of the University

- Cost

- Curiosity in the distance learning experience

- Learning through technology

- No requirement to quit the job

- Pre-requisite/mandatory for my job

- Career growth and advancements

- Status symbol

- Family pressure

- Higher income

- Compete in job market 
- Personal satisfaction

- Long-term career objectives

- To facilitate Career change

- Programme duration

- Local accreditation

- Overall accreditation

- Ranking of the university

- Study materials provided

- Location of study centers

\section{Results}

The data collected were analyzed using descriptive statistics and the factor rating method using SPSS 16.0. The Table 1 shows the characteristic of the sample by age and gender.

Table 1.Characteristics of Sample by age and gender

\begin{tabular}{|l|c|c|c|}
\hline \multirow{2}{*}{$\begin{array}{l}\text { Age } \\
\text { Group }\end{array}$} & \multicolumn{2}{|c|}{ Gender } & \\
\cline { 2 - 4 } & Male & Female & Total \\
\hline $20-25$ & 0 & 6 & 6 \\
\hline $26-30$ & 2 & 6 & 8 \\
\hline $31-35$ & 12 & 5 & 17 \\
\hline $36-40$ & 1 & 5 & 6 \\
\hline $41-45$ & 4 & 3 & 7 \\
\hline $46-50$ & 2 & 1 & 3 \\
\hline $55-60$ & 0 & 1 & 1 \\
\hline Total & 21 & 27 & 48 \\
\hline$\%$ Total & 43.8 & 56.2 & 100.0 \\
\hline
\end{tabular}

For the twenty-five factors in the study the responses were made by marking each factor according to a five point scale. Participant response to each factor was coded as 'not important' (1) to very important (5). As shown in Table 2, remarkably the two reasons: interest in the subject and the reputation of the university received the same highest mean scores followed by the reputation of course (with means of 4.75 and 4.69 respectively). These two reasons were closely followed by personal satisfaction with mean of 4.67 and ranking of the university and study materials received the same mean score of 4.65 .

Individual reliability of each item is evaluated by examining the loadings. The reliability analysis using Cronbach's Alpha was found to be 0.862 for the twenty-five items. In exploratory research, Cronbach's alpha should exceed or equal of over 0.6 [29], and items considered in our scale qualify above the stipulated value.

To understand the factors considered for enrollment of students towards the distance education, the measure of sampling adequacy using
Kaiser-Meyer-Olkin (KMO) measure of sampling adequacy was found to be 0.57 and Bartlett's test of Sphericity is significant at 0.000 . Hence a factor analysis was performed using the principal component analysis extraction method and orthogonal rotation method of varimax which is used to identify possible groupings from the items. In order to set a criterion for selecting the items, only those which loaded 0.5 or more were retained. Of the twenty-five items two items - distance education

Table 2. Mean scores of factors

\begin{tabular}{|l|c|c|}
\hline & Mean & $\begin{array}{c}\text { Std. } \\
\text { Deviation }\end{array}$ \\
\hline Interest in subject & 4.75 & .526 \\
\hline Reputation University & 4.75 & .565 \\
\hline Reputation Course & 4.69 & .589 \\
\hline Personal satisfaction & 4.67 & .630 \\
\hline Ranking university & 4.65 & .668 \\
\hline Study materials & 4.65 & .565 \\
\hline No quitting job & 4.60 & .736 \\
\hline Career growth advancement & 4.50 & .744 \\
\hline Long term career objective & 4.44 & .681 \\
\hline Location of study centre & 4.40 & .893 \\
\hline Facilitate career change & 4.33 & .753 \\
\hline Programme duration & 4.23 & .857 \\
\hline Time flexibility & 4.23 & .905 \\
\hline Compete job market & 4.19 & .867 \\
\hline Overall accreditation & 4.12 & 1.104 \\
\hline Local accreditation & 4.10 & 1.016 \\
\hline Prerequisite mandatory & 4.06 & .998 \\
\hline Reputation teacher & 3.96 & .898 \\
\hline Cost & 3.92 & 1.007 \\
\hline Learning technology & 3.90 & .928 \\
\hline Status symbol & 3.88 & .981 \\
\hline Curiosity to study through & 3.79 & .824 \\
\hline distance & & \\
\hline Higher income & 3.77 & 1.134 \\
\hline No Physical presence & 3.67 & .930 \\
\hline Family pressure & 2.23 & 1.372 \\
\hline
\end{tabular}

provides time flexibility and learning through technology were having less than 0.5 loading and hence not included. The factor rating method highlighted nine factors as shown in table 3. 
Table 3. Factor and factor loadings

\begin{tabular}{|l|l|}
\hline No. of Factors & Loading \\
\hline Factor -1 & \\
\hline Local accreditation & .913 \\
\hline Overall accreditation & .868 \\
\hline Programme duration & .612 \\
\hline Factor -2 & \\
\hline Reputation University & .875 \\
\hline Reputation Course & .828 \\
\hline Factor -3 & \\
\hline Career growth advancement & .866 \\
\hline Interest in subject & .741 \\
\hline Higher income & .644 \\
\hline Reputation of teacher & .631 \\
\hline Factor -4 & \\
\hline No quitting of job & .799 \\
\hline Location study center & .764 \\
\hline Study materials & .692 \\
\hline Factor -5 & \\
\hline No Physical presence required & .724 \\
\hline Family pressure & .685 \\
\hline Status symbol & .659 \\
\hline Cost & .648 \\
\hline Factor -6 & \\
\hline Compete job market & .892 \\
\hline Long term career objective & .690 \\
\hline Factor -7 & \\
\hline Curiosity distance & .775 \\
\hline Prerequisite mandatory & .513 \\
\hline Factor -8 & \\
\hline Ranking university & .806 \\
\hline Facilitate career change & \\
\hline Factor -9 & \\
\hline Personal satisfaction & \\
\hline
\end{tabular}

The factors were named as programme associated (factor 1), reputation (factor 2), personal development (factor 3), practical issues (factor 4), personal concerns (factor 5), competition and personal objectives (factor 6), personal motivators (factor 7), institutional status (factor 8) and personal satisfaction (factor 9).

\section{Discussion and implications}

It is evident from table 1 that both male and female are competing for better career or opportunity. It is clear that male in the age group of 31-35 are increasing pursing master programme as they are otherwise stuck at the entry level and naturally aim for superior level at work. Remarkably, the concern towards reputation of university and interest in the subject are having the highest ranks, and family pressure is having the lowest mean score. Surprisingly cost, higher income and family pressure are having lower mean score, which could be based on the subtle questions and the respondents are becoming conscious while answering the questionnaire. Hence, other forms of techniques such as projective techniques or a focus group method may have to be attempted to identify and explore these concerns.

The present study has identified nine factors programme-associated, reputation, personal development, practical issues, personal concerns, competition and personal objectives, personal motivators, institutional status and personal satisfaction that affect the student enrollment towards a distance education. Predominantly these factors are required to be examined by the educational institutes to better understand the requirements of the student community. Firstly, the factors such as programme-associated and reputation can be exercised control by the educational institutes. The accreditation both local and overall is important for the student and also the programme duration need to be well-managed by the educational institute. Also, the reputation of the university and the course is important and the institute/university needs to continuously enhance their reputation. Secondly, it is important to recognize the personal concerns that include cost, status symbol, family pressure and no physical presence required and these messages are communicated through advertising of the educational institute. Thirdly, understanding the practical issues that include no quitting of job, location of study center and study material are important for consideration so as to scale up the study centers as necessary. Hence the university needs to increase the branches of their study centers depending on the demographic and demand patterns. Further the quality of study materials have to improve on a continuous basis and up gradation of the topics and syllabus should be incorporated. Fourthly, personal objectives mainly competing in the job market and long term career objective

An interesting outcome of the present study is that, convenient time schedules a factor considered important has not found its place in the present study, which may be due to the low sample considered in the study or cultural differences. Hence 
the further study with large samples across the different states of India is required to be assessed.

\section{Scope for further Studies}

Further studies can be focused on one of the master's courses such as Masters of Business Administration and evaluate how the factors vary. Also comparative studies could be carried out among the different masters courses to identify the patterns of similarities and differences among them.

\section{References}

[1] M.A. Babatunde and R.A. Adefabi, "Long Run Relationship between Education and Economic Growth in Nigeria: Evidence from the Johansen's Cointegration Approach", Proceedings of the Regional Conference on Education in West Africa: Constraints and Opportunities Dakar, Senegal, November 1st - 2nd, 2005, pp. 1- 22.

[2] Christensen, C.M., Disrupting Class: How Disruptive Innovation Will Change the Way the World Learns, McGraw-Hill, New York, 2008.

[3] Edelson, P.J. and Pittman, V.V., "Historical perspectives on distance learning", in Bramble, W.J. and Panda, S. (Eds), Economics of Distance and Online Learning: Theory, Practice and Research, Routledge, New York, 2008.

[4]Edirisingha, P., "Open basic education: organizational structures, costs and benefits", in Bramble, W.J. and Panda, S. (Eds), Economics of Distance and Online Learning: Theory, Practice and Research, Routledge, New York, 2008, pp. 211-32.

[5] Low adoption of information technology tools in education sector is a major challenge', Interview with $\mathrm{Mr}$. Anil Goyal, Director Strategy and Business Development, Mexus Education, The Hindu Business Line, Saturday, January 28, 2012, Mangalore Edition, pp.6.

[6] Curran, C., "Online learning and the university", in Bramble, W.J. and Panda, S. (Eds), Economics of Distance and Online Learning: Theory, Practice and Research, Routledge, New York, 2008, pp. 26-51.

[7] Allen, I.E. and Seaman, J., Staying the Course: Online Education in the United States, The Sloan Consortium, Boston, 2008.

[8] Nixon, J.C and Helms, M.M., "Developing the virtual classroom: a business school examples", Education + Training, Vol.39 No.9, 1997, pp. 349-53.

[9] Simonson, M., Smaldino, S., Albright, M. and Zvacek, S., Teaching and Learning at a Distance: Foundations of Distance Education, Pearson Education, Boston, 2009.

[10] Moore, M.G. and Kearseley, G., Distance Education: A Systems View, Wadsworth, Belmont, 1996.
[11] Schrum, L. and Ohler, J., "Distance education at UAS: a case study", Journal of Distance Education, Vol. 20 No. 1, 2005, pp. 60-83.

[12] H.M.G. Miller, "Agriculture distance education: A valid alternative for higher education?" Proceedings of the 20th Annual National Agricultural Education Research Meeting, December 1993, pp. 67-73.

[13] Holmberg, B, Growth and Structure of Distance Education, Croom Helm, London, 1986.

[14] Cheng, Y.C, "Fostering local knowledge and human development in globalization of education", The International Journal of Educational Management, Vol. 18, No. 1, 2004, pp. 7-24.

[15] King, R., "What is higher education for? Strategic dilemmas for the twenty first century university", Quality Assurance in Education, Vol. 3 No. 4, 1995, pp. 14-20.

[16] McIsaac, M.S. and Gunawardena, C.N., "Distance education", in Jonassen, D.H. (Ed.), Handbook of Research for Educational Communications and Technology, 1st ed., Lawrence Erlbaum Associates, Mahwah, NJ, 1996, pp. 403-38.

[17] Rumble, G., The Planning and Management of Distance Education, Croom Helm, London, 1986.

[18]Holmberg, B., Growth and Structure of Distance Education, Croom Helm, London, 1986.

[19] Holmberg, B., Theory and Practice of Distance Education, Routledge, London, 1989.

[20] Keegan, D., "Problems in defining the field of distance education", The American Journal of Distance Education, Vol. 2 No. 2, 1988, pp. 4-11.

[21] Holmberg, B., Theory and Practice of Distance Education, 2nd ed., Routledge, London, 1995.

[22] Baynton, M., "Dimensions of control in distance education: a factor analysis", The American Journal of Distance Education, Vol. 6 No. 2, 1992, pp. 17-31.

[23] Moore, M., "Introduction", in Moore, M. (Ed.), Background and Overview of Contemporary American Distance Education, Contemporary Issues in American Distance Education, Pergamon Press, New York, 1990, pp. i-vii.

[24] MacBrayne, PS "Rural adults in community college distance education: what motivates them to enroll", New Directions for Community Colleges, Vol.23 No. 2, 1995, pp.85-93.

[25] Sherry, L, "Issues in distance learning", International Journal of Educational Telecommunications, Vol.1, No.4, 1997, pp.337-365.

[26] Jarmon, C, Frshee, D, Olcott, D, Boaz, M and Hardy, D, Teaching at a Distance: A Handbook for Instructors, Harcourt Brace, USA, 1998.

[27] Ridley, DR, Bailey, BL, Davies, ES, Hash, SG and Varner, DA, Evaluating the Impact of On-line Course 
International Journal of Digital Society (IJDS), Volume 3, Issue 3, June 2012

Enrollments on FTEs at an Urban University, AIR 1997 Annual Forum Paper.

[28] Rasmussen, CA (1993) Identification and analysis of factors that influence adult students to participate in distance learning programs, Dissertation Abstracts International, 53, 7-A, 2344.

[29]Nunnaly, J, Psychometric theory, McGraw-Hill, USA, 1978. 